\title{
Frostid: Aplikasi Pelaporan Jalan Banjir Berbasis Warga Pada Navigasi Berlalu Lintas
}

\author{
Frostid: Crowdsourcing-based Flooded Road Reporting Application on Traffic \\ Navigation Maps
}

\author{
Eka Prakarsa Mandyartha ${ }^{1}$, Asif Faroqi ${ }^{2}$ \\ ${ }^{1}$ Program Studi Informatika, Universitas Pembangunan Nasional "Veteran" Jawa Timur \\ ${ }^{2}$ Program Studi Sistem Informasi, Universitas Pembangunan Nasional "Veteran" Jawa Timur \\ E-mail: 1eka_prakarsa.fik@upnjatim.ac.id, 2asiffaroqi.si@upnjatim.ac.id
}

\begin{abstract}
Abstrak
Di Indonesia, banjir merupakan masalah utama yang dialami saat musim penghujan setiap tahunnya. Jalan banjir membawa dampak kerugian kepada pengendara kendaraan bermotor misalnya dapat menyebabkan kerusakan mesin, serta penyebab utama terjadinya karat pada kendaraan bermotor. Oleh karena itu, diperlukan upaya peringatan dini, berupa sistem pelaporan banjir, yang memberikan informasi kepada pengendara sehingga mereka dapat mengantisipasi jalan banjir. Pada penelitian ini diusulkan aplikasi pelaporan jalan banjir secara online yang berfokus pada peta navigasi berlalu-lintas untuk pengguna jalan. Aplikasi ini melibatkan partisipasi warga secara aktif (crowdsourcing) yaitu pengumpulan dan penyebaran informasi banjir dilakukan oleh kerumunan (crowd) warga dan dinamakan dengan Flooded Road Reporting System Indonesia (Frostid). Aplikasi mobile Frostid dikembangkan dalam lingkungan sistem operasi Android. Pendekatan pengembangan agile Mobile-D diterapkan. Penerimaan pengguna terhadap aplikasi dievaluasi menggunakan model TAM (Technology Acceptance Model). Metriks yang dievaluasi meliputi kegunaan yang dirasakan, kemudahan pengunaan yang dirasakan, sikap pengguna terhadap aplikasi, dan niat untuk menggunakan. Berdasarkan hasil analisis statistik deskriptif hasil pengujian penerimaan pengguna, dapat disimpulkan bahwa konsep crowdsourcing dalam aplikasi pelaporan jalan banjir diterima oleh pengguna. Kesediaan pengguna untuk merekomendasikan kepada orang lain, juga selaras dengan konsep crowdsourcing, dimana nilai dari aplikasi akan optimal jika banyak pengguna yang berkontribusi.
\end{abstract}

Kata kunci: sistem pelaporan, jalan, banjir, crowdsourcing, warga

\begin{abstract}
In Indonesia, flood is the main problem experienced during the rainy season each year. Flooded roads have a detrimental impact on vehicle drivers, such as engine damage, as well as the main cause of rust on vehicles. Therefore, it requires early warning reporting system to local people. This research proposes an online flood road reporting application that focuses on traffic navigation maps for road users. This application involves active citizen participation (crowdsourcing), and is called the Flooded Road Reporting System Indonesia (Frostid). Frostid mobile applications are developed in the Android operating system environment and adopted agile Mobile-D development approach. User acceptance of the application is evaluated through the TAM (Technology Acceptance Model) model. The evaluated metrics include the perceived usefulness, the perceived ease of use, the user's attitude towards the application, and the intention to use it. Based on the results of user acceptance testing, it can be concluded that the crowdsourcing concept in the Frostid application is accepted by users. The willingness of users to recommend to others is also in line with the crowdsourcing concept, where the value of the application will be optimal if many users contribute to such an application.
\end{abstract}

Keywords: reporting system, road, flood, crowdsourcing 


\section{PENDAHULUAN}

Infrastruktur seringkali dianggap sebagai tulang punggung sebuah kota [1]. Jaringan infrastruktur merupakan aspek penting dalam mengelola kota yang layak huni serta layak secara ekonomi [1]. Infrastruktur jalan adalah salah satu bentuk jaringan infrastruktur. Infrastruktur jalan dibangun untuk mendukung kesejahteraan masyarakat, terutama dalam perekonomian, yang sangat bergantung pada mobilitas manusia dan barang. Perubahan cuaca ekstrim yang mengakibatkan banjir dapat mempengaruhi kualitas ketersediaan infrastruktur jalan bagi masyarakat.

Di Indonesia, banjir, terutama banjir bandang merupakan masalah utama yang dialami saat musim penghujan setiap tahunnya. Banjir bandang terjadi ketika permukaan sungai naik karena tingginya curah hujan, waduk yang tidak mampu menampung volume air hujan atau sistem drainase yang kurang baik. Ketinggian air yang melebihi tepian sungai, dapat mengakibatkan daerah di sekitar sungai tergenang air. Banjir dapat terjadi karena daya dukung tanah yang rendah sehingga terjadi kenaikan air tanah, yang dapat menyebabkan banjir skala besar [2].

Banjir juga dapat disebabkan oleh badai atau topan, atau naiknya permukaan laut karena perubahan iklim atau berasal dari gelombang tsunami. Selain itu, banjir dapat disebabkan oleh aliran air hujan yang gagal mengalir ke dalam sistem drainase atau selokan karena kapasitas selokan penuh, jalan telah terendam air sebelumnya dan struktur jalan yang mengakibatkan air tidak mengalir ke sistem drainase. Permasalahan infrastruktur jalan terendam banjir terutama terjadi di daerah perkotaan, misalnya Jakarta dan Surabaya, disebabkan karena tingginya angka permukaan yang impermeable (tanah tidak mampu menyerap air) sehingga mencegah infiltrasi air ke dalam tanah.

Seiring dengan perubahan iklim, frekuensi dan tingkat keparahan bencana alam terkait cuaca akan meningkat sehingga mempengaruhi lebih banyak masyarakat melalui banjir [2], [3]. Jalan terendam banjir, bila dilalui oleh kendaraan bermotor, akan sangat merugikan pengendaranya. Air banjir dapat merusak mesin, transmisi, komponen-komponen listrik, serta sistem komputer elektronik kendaraan bermotor. Air juga sangat membahayakan perangkatperangkat keselamatan kendaraan mobil, seperti kantung udara (airbag) dan sistem pengereman yang menggunakan ABS (Anti-lock Braking System). Selain itu, mungkin dijumpai masalah kesehatan yang melibatkan jamur dan bakteri, karena kendaraan lembab, terutama pada mobil. Masalah-masalah lain yang berhubungan dengan air mungkin tidak segera terlihat, misalnya karat dan korosi yang akan berkembang seiring waktu.

Sistem pelaporan banjir merupakan salah satu upaya peringatan dini yang memberikan informasi kepada warga agar dapat melakukan langkah antisipasi. Penelitian yang diusulkan oleh Cools, dkk [4] merekomendasikan keterlibatan warga lokal dalam pengumpulan informasi banjir sehingga informasi itu dapat digunakan sebagai peringatan dini. Keterlibatan warga dalam pengumpulan informasi untuk pemantauan lingkungan menjadi semakin umum dan sering disebut juga dengan crowdsourcing [2], [5]. Meskipun crowdsourcing umumnya diterapkan di bidang konservasi dan keanekaragaman hayati, tetapi baru-baru ini, juga diterapkan dalam berbagai ranah di bidang geosains [2], [6]. Pendekatan crowdsourcing memberdayakan "kerumunan" ( crowd) untuk mengumpulkan data yang memadai ke dalam basis pengetahuan melalui media internet [7]-[9]. Data atau pengetahuan yang diberikan oleh kerumunan kemudian dibagikan kepada pengguna lainnya sebagai tujuan utamanya.

Beberapa aplikasi pada literatur telah diusulkan untuk pelaporan banjir secara online meliputi pengumpulan data dan penyebaran informasi banjir kepada warga. Pengumpulan data berbasis sistem sensor memiliki keterbatasan dalam hal cakupan wilayah, oleh karena itu dipertimbangkan penggunaan sensor seluler yang meliputi jaringan seluler nirkabel dan perangkat seluler yang tersemat sensor GPS (Global Positioning System) yang dapat dibawa oleh pengguna di lokasi untuk mengumpulkan data terkait banjir [7], [10], [11]. Penelitian yang diusulkan oleh Eilander, dkk [12] membuat peta banjir Jakarta berbasis sosial media dengan mengkombinasikan Digital Elevation Model dengan data lokasi pada konten tweet di Twitter. 
Peta probabilitas diperkenalkan untuk mengukur ketidakpastian data. Hasil validasi menunjukkan secara umum akurasi lokasi mencapai $69 \%$ dan meningkat menjadi $93 \%$ jika lokasi spesifik disebutkan dalam konten tweet. Ushaidi Crowdmap [13], sebuah aplikasi web 2.0 untuk crowdsourcing yang dikembangkan di Kenya, telah digunakan untuk pelaporan banjir di Australia [14]. Penelitian yang diusulkan oleh Koswatte, dkk [14] ini menganalisis secara semantik data tweet banjir Queensland di Twitter dan Ushaidi Crowdmap untuk mengekstraksi informasi lokasi banjir. Sistem serupa juga telah dikembangkan dengan mengintegrasikan Ushaidi Crowdmap untuk membangun peta krisis (Crisis Map) Republik Ceko selama banjir tahun 2013 [15]. Sistem pelaporan online lainnya yaitu aplikasi CrowdMonitor [16]. CrowdMonitor memberikan tugas pengumpulan data kepada warga selama keadaan darurat dari berbagai jenis bencana, termasuk segala jenis banjir. Beberapa aplikasi lain yang juga berfokus pada pelaporan dan pengelolaan banjir, diantaranya yaitu aplikasi yang menerapkan crowdsourcing untuk pengumpulan data spesifik dalam konteks darurat banjir [17] serta aplikasi survei infrastruktur parit, gorong-gorong, dan saluran air [18], untuk pengelolaan banjir dan kesiapan menghadapi banjir.

Beberapa aplikasi pendekatan crowdsourcing pengelolaan banjir pada literatur tersebut mengembangkan sistem manajemen bencana dan mitigasi banjir. Berbeda dari literatur-literatur tersebut, dalam penelitian ini diusulkan sistem pelaporan jalan banjir secara online, dinamakan sebagai Flooded Road Reporting System Indonesia (Frostid), yang berfokus pada peta navigasi berlalu-lintas untuk pengguna jalan. Dengan demikian, rumusan masalah pada penelitian ini adalah Bagaimana cara membangun aplikasi crowdsource Frostid menggunakan pendekatan pengembangan agile? serta Bagaimana mengukur penerimaan penggunanya dengan model TAM (Technology Acceptance Model)?

\section{METODE PENELITIAN}

Metodologi penelitian dilaksanakan dalam tiga tahapan yaitu perancangan penelitian, pengembangan perangkat lunak (aplikasi mobile dan web), dan evaluasi.

\subsection{Rancangan Penelitian}

Untuk membangun Frostid, Mobile-D [19] digunakan sebagai pendekatan pengembangan perangkat lunak yang berfokus pada pengembangan agile. Mobile-D memiliki siklus pengembangan yang singkat dan diarahkan untuk tim pengembang berjumlah kecil [20] sesuai dengan penelitian ini. Mobile-D terdiri dari lima tahapan [20], [21] sebagai berikut:

- Eksplorasi (Explore). Pada tahapan ini dilakukan perencanaan dan konsep dasar proyek. Ruang lingkup dan kebutuhan fungsionalitas sistem ditetapkan.

- Inisialisasi (Initialize). Pada tahapan ini proyek dikonfigurasi. Seluruh sumber daya yang diperlukan disiapkan dan diverifikasi. Lingkungan teknis proyek ditetapkan.

- Produksi (Productionize). Pada tahapan ini diimplementasikan seluruh fungsi yang diperlukan sistem.

- Stabilisasi (Stabilize). Pada tahapan ini dilakukan integrasi seluruh implementasi fungsi sistem. Verifikasi fungsi sistem keseluruhan dilakukan.

- Pengujian sistem (System test and fix). Pengujian sistem dilakukan untuk memverifikasi bahwa pengembangan telah sesuai dengan kebutuhan fungsionalitas. Selain itu

Definisi pengujian penerimaan pengguna. Pengujian penerimaan pengguna dilakukan untuk mendapatkan gambaran mengenai penerimaan pengguna terhadap aplikasi Frostid sebagai aplikasi berbasis crowdsourcing. Untuk mengukur penerimaan pengguna, model Technology Acceptance Model dipakai sebagai dasar penyusunan instrumen penelitian. Technology Acceptance Model (TAM) merupakan model penerimaan teknologi dengan dua konstruk utama yaitu kegunaan yang dirasakan (perceived usefulness) dan kemudahan penggunaan yang dirasakan (perceived ease of use) [22]. Kegunaan yang dirasakan mengacu pada perasaan pengguna tentang peningkatan kinerja saat mereka menggunakan teknologi. Kemudahan penggunaan yang dirasakan berkaitan dengan upaya yang dilakukan pengguna saat 
menggunakan teknologi. TAM telah diterapkan secara luas pada penelitian penerimaan pengguna dari berbagai jenis teknologi.

Pengukuran penerimaan pengguna. Untuk mengukur penerimaan pengguna, digunakan dua konstruk utama model TAM yaitu kegunaan yang dirasakan serta kemudahan penggunaan yang dirasakan. Instrumen pengukurannya berupa kuesioner survei kepada pengguna Frostid. Tabel 1 menunjukkan daftar pertanyaan beserta variabel pengukurannya.

Tabel 1 Daftar Pertanyaan dan Variabel Pengukuran dari Kuesioner Penerimaan Pengguna

\begin{tabular}{|c|c|}
\hline Variabel & Pertanyaan \\
\hline \multirow{3}{*}{$\begin{array}{l}\text { Kegunaan yang dirasakan } \\
\text { (perceived usefulness) }\end{array}$} & Frostid berguna bagi saya \\
\hline & Frostid memberi saya kemudahan untuk berbagi informasi jalan banjir \\
\hline & Frostid memberi saya kemudahan untuk mendapatkan informasi jalan banjir \\
\hline \multirow{2}{*}{$\begin{array}{l}\text { Kemudahan Penggunaan yang } \\
\text { dirasakan (perceived ease of } \\
\text { use) }\end{array}$} & Bagi saya, Frostid mudah digunakan \\
\hline & Mempelajari cara menggunakan Frostid tidak begitu sulit bagi saya \\
\hline \multirow[t]{3}{*}{ Sikap Perilaku (attitude) } & Menggunakan Frostid adalah ide yang bagus \\
\hline & Frostid layak untuk dicoba \\
\hline & Menurut saya, aplikasi Frostid ini bagus \\
\hline \multirow[t]{2}{*}{$\begin{array}{l}\text { Niat untuk Menggunakan } \\
\text { (intention) }\end{array}$} & $\begin{array}{l}\text { Saya akan menggunakan aplikasi Frostid untuk melaporkan dan mendapatkan informasi jalan } \\
\text { banjir }\end{array}$ \\
\hline & Saya akan merekomendasikan aplikasi Frostid kepada orang lain \\
\hline
\end{tabular}

Masing-masing item pertanyaan dievaluasi menggunakan skala Likert 5-titik meliputi Sangat Setuju (SS), Setuju (S), Netral (N), Tidak Setuju (TS), dan Sangat Tidak Setuju (STS).

\subsection{Pengembangan Perangkat Lunak}

Sesuai dengan metodologi Mobile-D, pengembangan perangkat lunak Frostid terdiri dari lima tahapan sebagai berikut:

Tahapan Eksplorasi. Aplikasi mobile Frostid memiliki fitur sebagai berikut: yaitu melakukan registrasi, melakukan login, menambah laporan banjir, menghapus laporan banjir, melihat daftar laporan banjir, melihat peta lokasi banjir, melihat detil laporan banjir, mereset password, dan melaporkan bug. Kebutuhan fungsional Frostid divisualisasikan dalam diagram use case yang ditunjukkan pada Gambar 1.

Tahapan inisialisasi. Lingkungan pengembangan sistem Frostid didefinisikan pada Tabel 2. Selain itu, arsitektur sistem didefinisikan, yang terdiri dari dua komponen utama, yaitu aplikasi mobile Frostid, dan support system. Aplikasi mobile Frostid berkomunikasi dengan support system melalui cloud server. Support system berfungsi untuk mendukung penyimpanan dan penyediaan data aplikasi Frostid melalui database server. Sebuah antarmuka, Application Programming Interface (API), diperlukan untuk komunikasi antara aplikasi mobile dengan database server. Antarmuka tersebut terletak di sisi support system di dalam cloud server. Arsitektur sistem ditunjukkan pada Gambar 2.

Tahapan Produksi. Pengembangan sistem dilakukan berdasarkan iterasi yang dimunculkan pada tahap inisialisasi. Langkah pertama yaitu merancang basis data relasional yang digunakan untuk menyimpan informasi. Selanjutnya adalah implementasi kebutuhan fungsional sistem ke dalam fungsi-fungsi program, dan pembuatan antarmuka.

Tahapan Stabilisasi. Integrasi semua fungsi dilakukan, fungsi sistem diverifikasi. Selanjutnya dilakukan penyempurnaan antarmuka, dan pada fase akhir, pembuatan dokumentasi dilakukan seperti manual pengguna. Halaman utama Frostid ditunjukkan pada Gambar 3. Halaman ini berisi peta navigasi berlalu-lintas yang memberikan informasi titik banjir. Titik banjir direpresentasikan oleh ikon air. Ikon air melambangkan level banjir. Level banjir terbagi menjadi tiga yaitu level rendah, level sedang, dan level tinggi. 


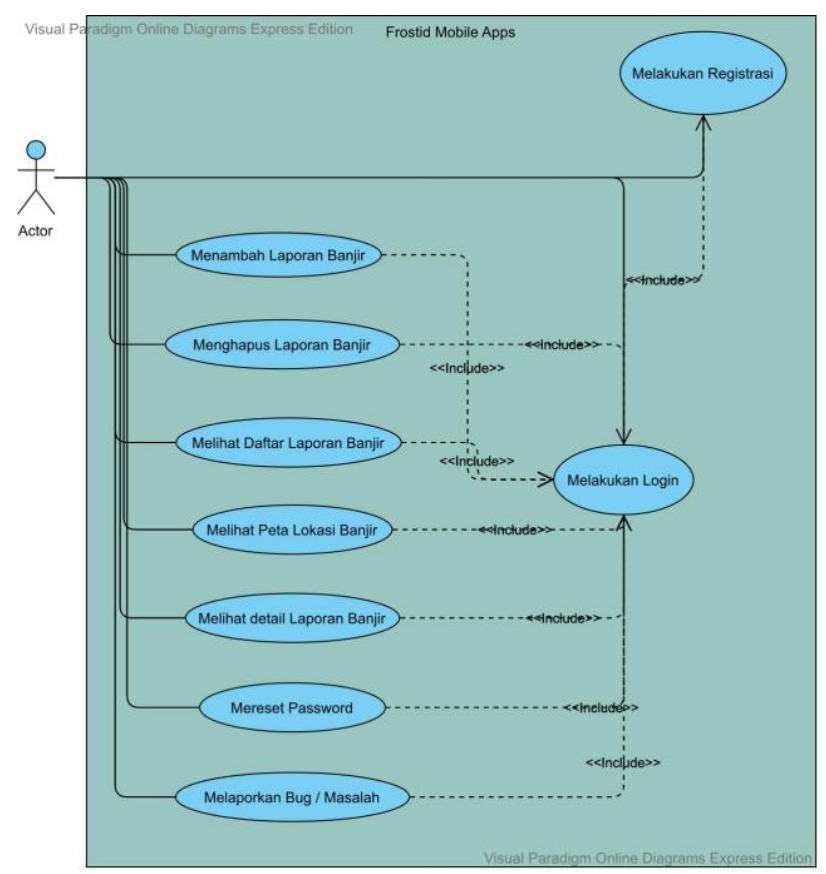

Gambar 1 Diagram use case Frostid

Tabel 2 Lingkungan Pengembangan Sistem Frostid

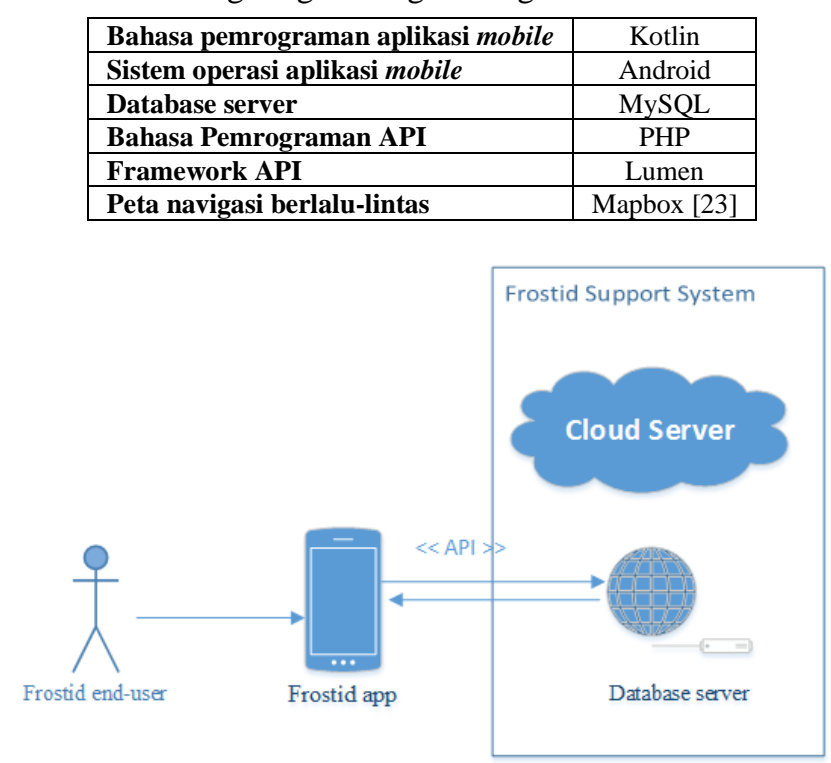

Gambar 2 Arsitektur Sistem Frostid.

Halaman tambah laporan banjir ditunjukkan pada Gambar 4. Pada halaman tambah laporan banjir, pengguna wajib memilih level banjir, sedangkan foto laporan dan deskripsi tidak wajib diisi.

Tahapan Pengujian. Rencana pengujian unit dibuat sesuai dengan kebutuhan fungsional. Setelah selesai, koreksi dan perbaikan kemungkinan kesalahan dilakukan. Dengan cara ini, sistem tersedia sesuai dengan kebutuhan fungsional pengguna. Selain itu dilaksanakan tes penerimaan pengguna terhadap aplikasi menggunakan model TAM. 


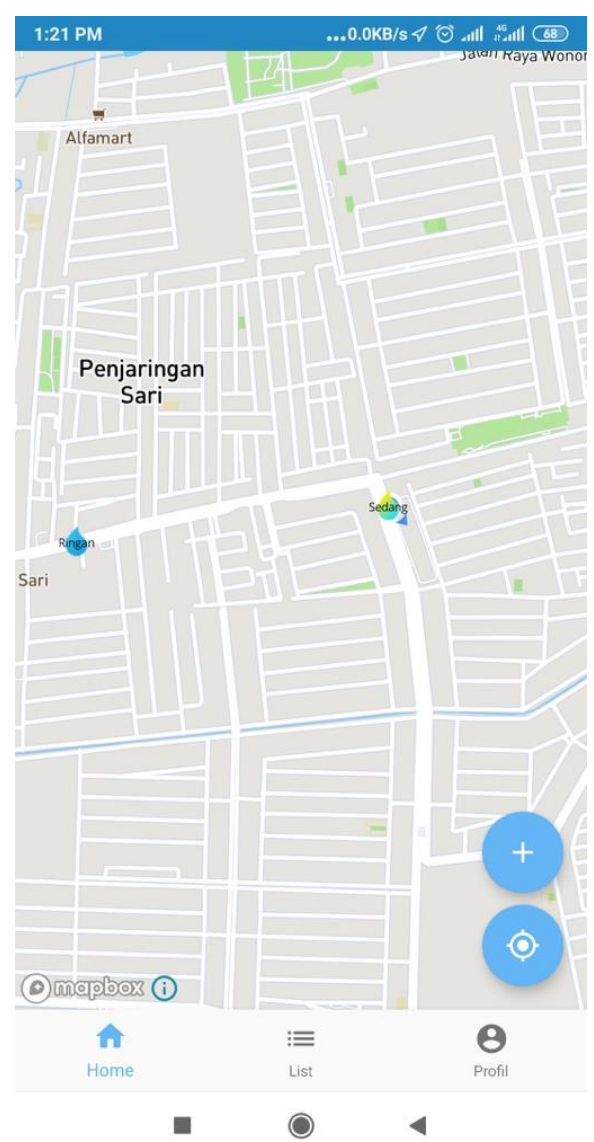

Gambar 3 Halaman Utama (Maps)

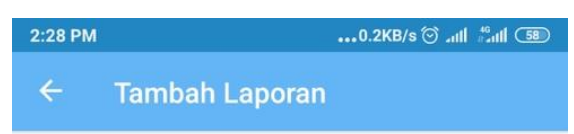

Foto Laporan

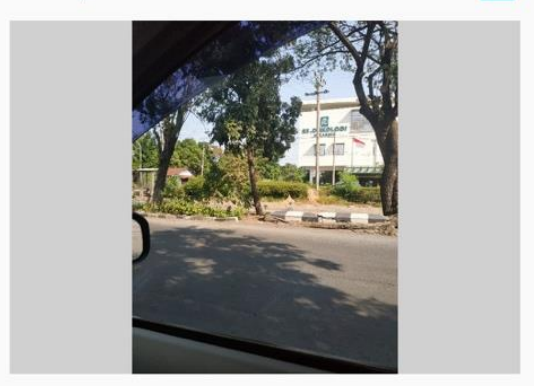

Level Banjir

Tinggi

Banjir agak dalam. Mobil sedan dan sejenisnya disarankan lewat jalur lain

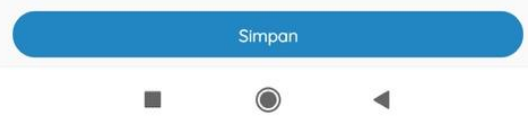

Gambar 4 Halaman Tambah Laporan Banjir

\section{HASIL DAN PEMBAHASAN}

Hasil yang diperoleh dianalisis dalam dua pendekatan pengujian yaitu pengujian blackbox untuk menguji fungsionalitas aplikasi dan pengujian penerimaan pengguna. Pengujian blackbox bertujuan untuk memastikan aplikasi telah memenuhi kebutuhan fungsional yang telah ditentukan. Skenario pengujian dilakukan berdasarkan use case pada tahapan eksplorasi. Tabel 3 mendeskripsikan hasil pengujian fungsional aplikasi mobile Frostid.

Tabel 3 Hasil Pengujian Fungsional Aplikasi Mobile Frostid

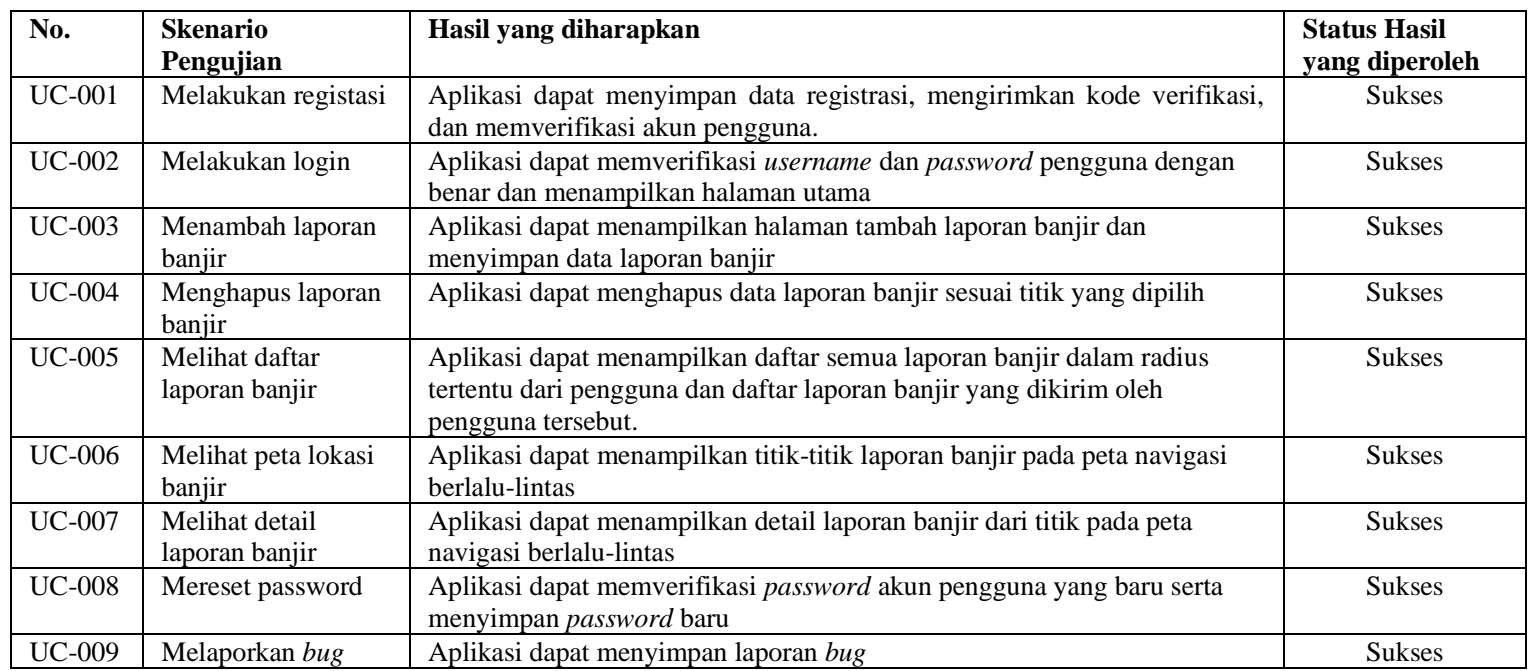


Berdasarkan hasil pengujian aplikasi yang ditunjukkan pada Tabel 3, bahwa aplikasi Frostid telah memenuhi kebutuhan fungsional yang telah didefinisikan.

Hasil pengujian penerimaan pengguna. Pengujian penerimaan pengguna diselesaikan dengan melakukan survei terhadap 130 responden yang terdiri dari pekerja maupun mahasiswa, dan merupakan pengendara kendaraan bermotor. Analisis statistik deskriptif digunakan untuk membantu mendeskripsikan hasil pengisian instrumen kuesioner penelitian oleh pengguna aplikasi Frostid. Sebanyak 110 hasil kuesioner yang dikembalikan oleh responden, kemudian dihitung nilai rerata dari masing-masing konstruk TAM. Nilai rata-rata yang mendekati satu, dapat dikatakan persepsi pengguna semakin tidak setuju dengan pernyataan. Sedangkan nilai rerata mendekati lima, memberi indikasi persepsi pengguna semakin setuju dengan pernyataan. Tabel 4 menggambarkan perhitungan nilai rerata dari masing-masing konstruk.

Tabel 4 Perhitungan Rerata Konstruk Model TAM

\begin{tabular}{|l|c|}
\hline Konstruk & Nilai Rerata \\
\hline Kegunaan yang dirasakan (perceived usefulness) & 4,28 \\
\hline Kemudahan penggunaan yang dirasakan (perceived ease of use) & 4,22 \\
\hline Sikap terhadap aplikasi Frostid (attitude) & 4,46 \\
\hline Niat menggunakan aplikasi Frostid (intention) & 4,20 \\
\hline
\end{tabular}

Hasil perhitungan nilai rerata memberikan gambaran bahwa pengguna aplikasi Frostid secara umum memberikan umpan balik yang sangat positif. Berdasarkan Tabel 4 terlihat sikap terhadap aplikasi Frostid memiliki nilai rerata 4,46. Hal ini mengindikasikan bahwa pengguna setuju dan menyadari bahwa aplikasi Frostid layak untuk dicoba. Persepsi positif tersebut dirasakan karena pengguna menganggap aplikasi Frostid bermanfaat dan mudah digunakan. Hal tersebut terlihat pada konstruk kegunaan dan kemudahan penggunaan yang memiliki nilai rerata masing-masing 4,28 dan 4,22. Pengguna Frostid menyadari manfaat menggunakan aplikasi frostid, baik untuk mendapatkan informasi maupun berbagi informasi jalan banjir. Sedangkan konstruk niat menggunakan memiliki nilai rata-rata 4,20, mengindikasikan bahwa pengguna memiliki keinginan untuk menggunakan aplikasi Frostid untuk pelaporan jalan banjir dan bersedia untuk merekomendasikannya kepada orang lain.

\section{KESIMPULAN DAN SARAN}

Pada penelitian ini dibangun sebuah aplikasi yang menggunakan pendekatan crowdsourcing untuk memberikan informasi jalan banjir kepada pengguna jalan khususnya pengendara kendaraan bermotor di Indonesia. Semua informasi jalan banjir yang diakomodasi dalam aplikasi Frostid, dibangun seutuhnya oleh partisipasi penggunanya. Aplikasi Frostid berjalan pada perangkat mobile Android. Frostid dibangun menggunakan pendekatan pengembangan agile pada platform mobile yaitu metodologi Mobile-D. Lima tahapan pengembangan dilalui yaitu tahapan eksplorasi, inisialisasi, produksi, stabilisasi serta pengujian sistem dan perbaikan. Hasil pengujian fungsionalitas menggunakan metode black box menunjukkan bahwa aplikasi Frostid dapat berjalan dengan baik dan memenuhi kebutuhan fungsionalnya.

Berdasarkan hasil analisis statistik deskriptif hasil pengujian penerimaan pengguna terlihat bahwa pengguna setuju dan menyadari manfaat dari aplikasi Frostid dan kemudahan penggunaannya. Selain itu, pengguna berkeinginan menggunakan aplikasi Frostid dan bersedia untuk merekomendasikannya kepada orang lain. Secara tidak langsung, dapat dikatakan bahwa konsep crowdsourcing dalam aplikasi pelaporan jalan banjir diterima oleh pengguna. Kesediaan pengguna untuk merekomendasikan kepada orang lain, juga selaras dengan konsep crowdsourcing, dimana nilai dari aplikasi ini akan optimal jika banyak pengguna yang berkontribusi.

Pada roadmap selanjutnya, aplikasi Frostid akan dikembangkan dengan mengintegrasikan sistem cerdas yang membantu menentukan rute jalan bagi pengendara untuk 
menghindari jalan banjir yang telah dilaporkan pengguna.

\section{UCAPAN TERIMA KASIH}

Terima kasih sebesar-besarnya kepada Lembaga Penelitian dan Pengabdian kepada Masyarakat (LPPM) Universitas Pembangunan Nasional "Veteran" Jawa Timur yang telah mendukung dan mendanai penelitian ini.

\section{DAFTAR PUSTAKA}

[1] M. Pregnolato, A. Ford, S. M. Wilkinson, and R. J. Dawson, "The impact of flooding on road transport: A depth-disruption function," Transp. Res. Part Transp. Environ., vol. 55, pp. 67-81, Aug. 2017, doi: 10.1016/j.trd.2017.06.020.

[2] L. See, "A Review of Citizen Science and Crowdsourcing in Applications of Pluvial Flooding," Front. Earth Sci., vol. 7, 2019, doi: 10.3389/feart.2019.00044.

[3] L. C. Degrossi, J. P. de Albuquerque, M. C. Fava, and E. M. Mendiondo, "Flood Citizen Observatory: a crowdsourcing-based approach for flood risk management in Brazil," in SEKE, Jul. 2014, pp. 570-575.

[4] J. Cools, D. Innocenti, and S. O'Brien, "Lessons from flood early warning systems," Environ. Sci. Policy, vol. 58, pp. 117-122, Apr. 2016, doi: 10.1016/j.envsci.2016.01.006.

[5] R. Bonney et al., "Citizen Science: A Developing Tool for Expanding Science Knowledge and Scientific Literacy," BioScience, vol. 59, no. 11, pp. 977-984, Dec. 2009, doi: 10.1525/bio.2009.59.11.9.

[6] "Crowdsourcing Methods for Data Collection in Geophysics: State of the Art, Issues, and Future Directions - Zheng - 2018 - Reviews of Geophysics - Wiley Online Library." https://agupubs.onlinelibrary.wiley.com/doi/full/10.1029/2018RG000616 (accessed Mar. 23, 2020).

[7] Q. T. Minh, T. N. Chi, and M. Toulouse, "Toward a Crowdsourcing-Based Urban Flood Mitigation Platform," in Proceedings of the Eighth International Symposium on Information and Communication Technology, New York, NY, USA, Dec. 2017, pp. 301308, doi: 10.1145/3155133.3155153.

[8] M. Lease and E. Yilmaz, "Crowdsourcing for information retrieval," ACM SIGIR Forum, vol. 45, no. 2, pp. 66-75, Jan. 2012, doi: 10.1145/2093346.2093356.

[9] L. See et al., "Crowdsourcing, Citizen Science or Volunteered Geographic Information? The Current State of Crowdsourced Geographic Information," ISPRS Int. J. Geo-Inf., vol. 5, no. 5, Art. no. 5, May 2016, doi: 10.3390/ijgi5050055.

[10]H. N. Do, M.-T. Vo, V.-S. Tran, P. V. Tan, and C. V. Trinh, "An early flood detection system using mobile networks," in 2015 International Conference on Advanced Technologies for Communications (ATC), Oct. 2015, pp. 599-603, doi: 10.1109/ATC.2015.7388400.

[11]S. B. Serpico, S. Dellepiane, G. Boni, G. Moser, E. Angiati, and R. Rudari, "Information Extraction From Remote Sensing Images for Flood Monitoring and Damage Evaluation," Proc. IEEE, vol. 100, no. 10, pp. 2946-2970, Oct. 2012, doi: 10.1109/JPROC.2012.2198030.

[12]D. Eilander, P. Trambauer, J. Wagemaker, and A. van Loenen, "Harvesting Social Media for Generation of Near Real-time Flood Maps," Procedia Eng., vol. 154, pp. 176-183, 2016, doi: 10.1016/j.proeng.2016.07.441.

[13] "Ushahidi or 'testimony': Web 2.0 tools for crowdsourcing crisis information (PLA 59)," Jun. 2009, Accessed: Sep. 01, 2020. [Online]. Available: https://pubs.iied.org/G02842/.

[14]S. Koswatte, K. McDougall, and X. Liu, "VGI and crowdsourced data credibility analysis using spam email detection techniques," Int. J. Digit. Earth, vol. 11, no. 5, pp. 520-532, May 2018, doi: 10.1080/17538947.2017.1341558. 
[15]J. Pánek, L. Marek, V. Pászto, and J. Valůch, "The Crisis Map of the Czech Republic: the nationwide deployment of an Ushahidi application for disasters," Disasters, vol. 41, no. 4, pp. 649-671, 2017, doi: 10.1111/disa.12221.

[16]T. Ludwig, T. Siebigteroth, and V. Pipek, "CrowdMonitor: Monitoring Physical and Digital Activities of Citizens During Emergencies," in Social Informatics, Cham, 2015, pp. 421428, doi: 10.1007/978-3-319-15168-7_51.

[17]M. Middelhoff et al., "Crowdsourcing and crowdtasking in crisis management: Lessons learned from a field experiment simulating a flooding in the city of the Hague," in $20163 \mathrm{rd}$ International Conference on Information and Communication Technologies for Disaster Management (ICT-DM), Dec. 2016, pp. 1-8, doi: 10.1109/ICT-DM.2016.7857212.

[18]M. D. Hendricks et al., "The development of a participatory assessment technique for infrastructure: Neighborhood-level monitoring towards sustainable infrastructure systems," Sustain. Cities Soc., vol. 38, pp. 265-274, Apr. 2018, doi: 10.1016/j.scs.2017.12.039.

[19]P. Abrahamsson et al., "Mobile-D: an agile approach for mobile application development," in Companion to the 19th annual ACM SIGPLAN conference on Object-oriented programming systems, languages, and applications, New York, NY, USA, Oct. 2004, pp. 174-175, doi: 10.1145/1028664.1028736.

[20]A. Gordillo-Ramírez, O. Alonso-Cuevas, D. Ortega-Pacheco, and U. Vélez-Saldaña, "Mobile Application for the Support in the Learning of the Alphabet, Verbs and Pronouns of the Mexican Sign Language Based on Augmented Reality," in Telematics and Computing, Cham, 2019, pp. 183-191, doi: 10.1007/978-3-030-33229-7_16.

[21]A. Balaguera and Y. Daniel, "Metodologías ágiles y desarrollo de aplicaciones móviles," Univ. Inca Garcilaso Vega, Oct. 2013, Accessed: Dec. 15, 2020. [Online]. Available: http://repositorio.uigv.edu.pe/handle/20.500.11818/832.

[22]Y. Lu, T. Zhou, and B. Wang, "Exploring Chinese users' acceptance of instant messaging using the theory of planned behavior, the technology acceptance model, and the flow theory," Comput. Hum. Behav., vol. 25, no. 1, pp. 29-39, Jan. 2009, doi: 10.1016/j.chb.2008.06.002.

[23]"Mapbox." https://www.mapbox.com/ (accessed Mar. 23, 2020). 